Abstract SAT0341 - Table 1. Efficacy and safety results of an interim analysis of the extension period population of SPIRIT-P2.

\begin{tabular}{|c|c|c|c|c|}
\hline & $\begin{array}{c}\text { IXE Q4W } \\
(\mathrm{N}=111)\end{array}$ & $\begin{array}{c}\text { IXE Q2W } \\
(\mathrm{N}=107)\end{array}$ & $\begin{array}{c}\text { PBO/IXE Q4W } \\
(\mathrm{N}=46)\end{array}$ & $\begin{array}{c}\text { PBO/IXE Q2W } \\
(\mathrm{N}=46)\end{array}$ \\
\hline \multicolumn{5}{|c|}{ Week 52 Responder Rate, $n / N(\%), N R I$} \\
\hline ACR 20 & $\begin{array}{c}75 / 111 \\
(68)\end{array}$ & $\begin{array}{l}63 / 107 \\
(59)\end{array}$ & $\begin{array}{c}28 / 46 \\
(61)\end{array}$ & $\begin{array}{c}23 / 46 \\
(50)\end{array}$ \\
\hline ACR 50 & $\begin{array}{c}51 / 111 \\
(46)\end{array}$ & $\begin{array}{c}41 / 107 \\
(38)\end{array}$ & $\begin{array}{c}20 / 46 \\
(44)\end{array}$ & $\begin{array}{l}16 / 46 \\
(35)\end{array}$ \\
\hline ACR 70 & $\begin{array}{l}32 / 111 \\
(29)\end{array}$ & $\begin{array}{l}22 / 107 \\
(21)\end{array}$ & $\begin{array}{l}11 / 46 \\
(24)\end{array}$ & $\begin{array}{l}7 / 46 \\
(15)\end{array}$ \\
\hline MDA & $\begin{array}{c}42 / 111 \\
(38)\end{array}$ & $\begin{array}{l}29 / 107 \\
(27)\end{array}$ & $\begin{array}{l}14 / 46 \\
(30)\end{array}$ & $\begin{array}{c}13 / 46 \\
(28)\end{array}$ \\
\hline LEI $(0)^{a}$ & $\begin{array}{l}32 / 61 \\
(53)\end{array}$ & $\begin{array}{c}30 / 73 \\
(41)\end{array}$ & $\begin{array}{c}13 / 24 \\
(54)\end{array}$ & $\begin{array}{c}12 / 29 \\
(41)\end{array}$ \\
\hline LDI-B (0) ${ }^{b}$ & $\begin{array}{c}21 / 26 \\
(81)\end{array}$ & $\begin{array}{l}11 / 16 \\
(69)\end{array}$ & $\begin{array}{l}7 / 7 \\
(100)\end{array}$ & $\begin{array}{l}2 / 6 \\
(33)\end{array}$ \\
\hline PASI75 $^{\mathrm{C}}$ & $\begin{array}{c}41 / 62 \\
(66)\end{array}$ & $\begin{array}{c}37 / 57 \\
(65)\end{array}$ & $\begin{array}{c}19 / 25 \\
(76)\end{array}$ & $\begin{array}{c}15 / 31 \\
(48)\end{array}$ \\
\hline PASI90 & $\begin{array}{c}34 / 62 \\
(55)\end{array}$ & $\begin{array}{l}27 / 57 \\
(47)\end{array}$ & $\begin{array}{l}18 / 25 \\
(72)\end{array}$ & $\begin{array}{c}14 / 31 \\
(45)\end{array}$ \\
\hline NAPSI $(0)^{d}$ & $\begin{array}{c}41 / 81 \\
(51) \\
\end{array}$ & $\begin{array}{c}24 / 67 \\
(36) \\
\end{array}$ & $\begin{array}{c}10 / 29 \\
(34) \\
\end{array}$ & $\begin{array}{l}9 / 25 \\
(36) \\
\end{array}$ \\
\hline \multicolumn{5}{|c|}{ Week 52 Mean (SD) Change from Baseline, mBOCF } \\
\hline HAQ-DI & $-0.4(0.5)$ & $-0.4(0.5)$ & $-0.4(0.4)$ & $-0.2(0.5)$ \\
\hline DAS 28-CRP & $-2.2(1.5)$ & $-1.9(1.3)$ & $-2.0(1.3)$ & $-1.6(1.3)$ \\
\hline \multicolumn{5}{|c|}{ Safety Overview (Weeks 24-156), $n$ (\%) } \\
\hline TEAE & $\begin{array}{c}79 \\
(71)\end{array}$ & $\begin{array}{l}68 \\
(64)\end{array}$ & $\begin{array}{c}32 \\
(70)\end{array}$ & $\begin{array}{l}27 \\
(59)\end{array}$ \\
\hline SAE & $\begin{array}{l}6 \\
(5)\end{array}$ & $\begin{array}{c}4 \\
(4)\end{array}$ & $\begin{array}{l}2 \\
(4)\end{array}$ & $\begin{array}{c}3 \\
(7)\end{array}$ \\
\hline $\begin{array}{l}\text { Discontinued } \\
\text { due to } \mathrm{AE}\end{array}$ & $\begin{array}{c}2 \\
(2) \\
\end{array}$ & $\begin{array}{c}8 \\
(8) \\
\end{array}$ & $\begin{array}{c}0 \\
(0) \\
\end{array}$ & $\begin{array}{r}2 \\
(4) \\
\end{array}$ \\
\hline \multicolumn{5}{|c|}{ 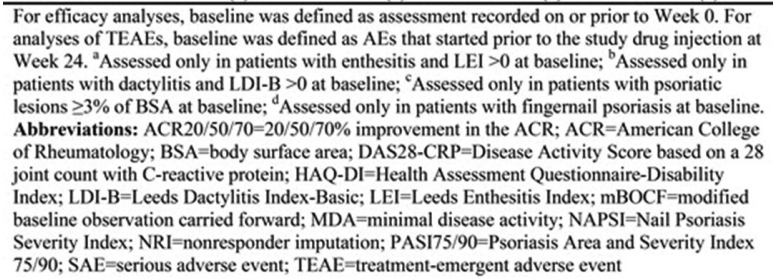 } \\
\hline
\end{tabular}

Conclusions: IXE demonstrated sustained improvement in the signs and symptoms of PsA across treatment groups during the EP. The safety profile of IXE observed in the EP population was consistent with the safety profile of the intentto-treat population in the DBTP of SPIRIT-P2. ${ }^{1}$

REFERENCE:

[1] Nash P, et al. Lancet 2017;389:2317-27.

Disclosure of Interest: M. Genovese Grant/research support from: Eli Lilly and Company, Abbvie, Galapagos, Pfizer, Consultant for: Eli Lilly and Company, Abbvie, Galapagos, Pfizer, B. Combe Grant/research support from: Pfizer, MSD, Roche-Chugai, Consultant for: Pfizer, UCB, Bristol-Myers Squibb, Janssen, Eli Lilly and Company, MSD, Roche-Chugai, AbbVie, Novartis, Speakers bureau: Pfizer, Bristol-Myers Squibb, Eli Lilly and Company, MSD, J. Kremer Shareholder of: Corrona, Grant/research support from: AbbVie, Novartis, Pfizer, Consultant for: AbbVie, Amgen, Bristol-Myers Squibb, Novartis, Pfizer, Employee of: Corrona, D. Adams Shareholder of: Eli Lilly and Company, Employee of: Eli Lilly and Company, C. Lee Shareholder of: Eli Lilly and Company, L. Kerr Shareholder of: Eli Lilly and Company, Employee of: Eli Lilly and Company, P. Nash Grant/ research support from: AbbVie, Bristol-Myers Squibb, Celgene, Eli Lilly and Company, Janssen, Novartis, Pfizer, Roche, Sanofi, UCB, Consultant for: AbbVie, Bristol-Myers Squibb, Celgene, Eli Lilly and Company, Janssen, Novartis, Pfizer, Roche, Sanofi, UCB, Speakers bureau: AbbVie, Bristol-Myers Squibb, Celgene, Eli Lilly and Company, Janssen, Novartis, Pfizer, Roche, Sanofi, UCB DOI: 10.1136/annrheumdis-2018-eular.2352

\section{SAT0342 INFLAMMATORY BACK PAIN IN PSORIATIC ARTHRITIS IS SIGNIFICANTLY MORE RESPONSIVE TO CORTICOSTEROIDS COMPARED TO BACK PAIN IN ANKYLOSING SPONDYLITIS: A PROSPECTIVE, OPEN- LABELLED, CONTROLLED PILOT STUDY}

M. Haroon ${ }^{1}$, M. Ahmad ${ }^{1}$, N. Baig ${ }^{2}$, O. Mason ${ }^{3}$, J. Rice ${ }^{2}$, O. FitzGerald ${ }^{4}$. ${ }^{1}$ Rheumatology; ${ }^{2}$ Orthopaedics, University Hospital Kerry, Tralee, County Kerry; ${ }^{3}$ CSTAR (Centre for Support and Training in Analysis and Research), University College Dublin; ${ }^{4}$ Rheumatology, St Vincent's University Hospital, Dublin, Ireland

Background: Inflammatory spinal disease is one of three inflammatory musculoskeletal manifestations which frequently occur in PsA. There is very limited data about the axial involvement in PsA, especially as regards treatment, with treatment guidelines based largely on data from AS trials. The efficacy of corticosteroids in PsA patients with inflammatory back pain has not been studied to date. Objectives: In this controlled trial, we aimed to investigate the comparative performance of corticosteroids for active axial-PsA (AxPsA) versus those with active AS

Methods: PsA patients (fulfilling CASPAR criteria), and AS as per the 1984 Modified New York Criteria, were suitable for inclusion. Among them, patients with active AxPsA and active AS ((naïve to biologic therapies) were recruited. The active disease was defined as patients with inflammatory back pain, with spinal pain score of $\geq 4$ and BASDAI score $\geq 4$ despite taking NSAIDS. Furthermore, only those AxPsA and AS patients with an MRI proven sacroiliac joint bone marrow oedema (MRI of sacroiliac joints performed within the 6 months prior to recruitment) were considered for inclusion. Hence, all recruited patients with AxPsA and AS had not only clinically active disease, but also had bone marrow oedema on MRI of sacroiliac joints. Moreover, we recruited a control group of noninflammatory lower back pain. All patients received a single, intra-muscular dose of depot corticosteroid injection (Triamcinolone Acetonide $80 \mathrm{mg}$ ) at baseline The intra-muscular corticosteroid option was used to overcome any drug compliance issues. Clinical outcome assessments were made at following time points: baseline, week-2, and week-4. The primary efficacy end point was the mean change in Ankylosing Spondylitis Disease Activity Score (ASDAS) at week-2. Key secondary outcome were the mean change of BASDAI, BASFI and ASQoL at week-2 and week-4

Results: In total, 40 patients were recruited $-\mathrm{AxPs} A=15, A S=15$, control=10. At week-2 following corticosteroid treatment, patients with AxPsA had significantly higher improvements in the mean ASDAS compared to patients with AS (1.43 \pm 0.39 vs. $1.03 \pm 0.30, p=0.004)$, and the same was the case when compared to controls $(p<0.001$, table- 2 , figure- 1 ). At week- 4 , AxPsA patients also showed significantly higher improvements in the mean ASDAS compared to both AS patients $(1.09 \pm 0.32$ vs. $0.77 \pm 0.27, p=0.007)$ and controls $(p<0.001)$. Similarly, the mean BASDAI, VAS spinal pain score, ASQoL and BASFI improved significantly among AxPsA patients compared to AS patients and controls at week-2, with this trend also largely maintained at week-4

Conclusions: Axial inflammation in PsA potentially responds significantly better to corticosteroids than in patients with AS. This furthers the argument and adds to the growing evidence that AxPsA and AS are distinct entities. Future studies should further investigate the use of corticosteroids and of SDMARD usage among patients with active IBP in PsA.

Disclosure of Interest: M. Haroon Grant/research support from: Abbie, Pfizer, Speakers bureau: Abbie, Pfizer, UCB, M. Ahmad: None declared, N. Baig: None declared, O. Mason: None declared, J. Rice: None declared, O. FitzGerald: None declared

DOI: 10.1136/annrheumdis-2018-eular.2560

\section{SAT0343 CARDIOVASCULAR DISEASE RISK IN CLINICAL SUBTYPES OF PSORIATIC ARTHRITIS}

N. Hassan ${ }^{1}$, M. Bradley ${ }^{2}$, R. Davies ${ }^{1}$, E. Choy ${ }^{1} .{ }^{1}$ Rheumatology, ${ }^{2}$ Cardiff University School of Medicine, Cardiff, UK

Background: Patients with psoriatic arthritis (PsA) have been shown to be at increased risk of developing cardiovascular disease (CVD), with one recent metaanalysis demonstrating an increased CVD risk of $43 \%$ compared to the general population. However PsA is a heterogeneous disease consisting of five different clinical subtypes. It is not known whether the risk of CVD varies between different PsA subtypes.

Objectives: To determine whether particular subtypes of PsA are associated with an increased risk of cardiovascular disease.

Methods: 114 patients with PsA attending the University Hospital of Wales were asked to complete a questionnaire about their cardiovascular risk factors. Anthro pometric and biochemical measurements, including blood pressure, body mass index (BMI), C-reactive protein (CRP) and cholesterol, were also performed. Patients were grouped into one of the five PsA subtypes as described by Moll and Wright. The QRISK2 algorithm was used to determine the 10 year risk of developing CVD for each patient. Multivariate analyses using linear and logistic regres sion with QRISK2 score and QRISK2 score $>10 \%$ as dependent variables were conducted and adjusted for known cardiovascular risk factors.

Results: Symmetrical polyarthritis was the most common subtype, no patients had arthritis mutilans. There were no statistically significant differences between the subtypes with regards to age, gender, BMI, blood pressure, smoking status, cholesterol or CRP. Statistically significant differences were found between the subtypes using Chi-square $(\chi 2)$ tests for QRISK2 score $>10 \%(p=0.031)$ as well as the presence of existing cardiovascular disease, diabetes mellitus and cholesterol lowering treatment $(p=0.021,0.021$ and 0.037 respectively). The table 1 below lists the number of patients by subtype and these variables. 